\title{
PENGARUH GARAM DAPUR DAN CUPRI SULPHAT TERHADAP PERTUMBUHAN ALGA CYANOPHYTA YANG DIISOLASI DARI BATU BATA BANGUNAN PURA DI DESA TEJAKULA BULELENG
}

\author{
${ }^{1}$ N. L. P. M. Widiyanti, ${ }^{2}$ | G. A N. Setiawan, ${ }^{3}$ I. A. P. Suryanti \\ 1,2,3Jurusan Pendidikan Biologi, Universitas Pendidikan Ganesha \\ Singaraja, Indonesia \\ E-mail : manikwidiyanti@gmail.com, gustiagungsetiawan@yahoo.com, \\ dayusuryanti@yahoo.co.id
}

\begin{abstract}
Abstrak
Penelitian ini mengenai pengaruh garam dapur $(\mathrm{NaCl})$ dan cupri sulphat $\left(\mathrm{CuSO}_{4}\right\}$ terhadap pertumbuhan alga Cyanophyta ini bertujuan untuk membandingkan pemberian variasi konsentrasi $\mathrm{NaCl}$ dengan $\mathrm{CuSO}_{4}$ dalam menghambat pertumbuhan alga Cyanophyta yang diisolasi dari batu bata bangunan Pura di desa Tejakula Buleleng. Penelitian eksperimental ini menggunakan rancangan penelitian the randomized pre-post-test control group design. Prosedur kerja diawali dengan pengumpulan data, pengamatan objek dengan menghitung jumlah alga cyanophyta pada media pertumbuhan yang diberikan konsentrasi garam dapur dan cupri sulphat dengan konsentrasi $0 \%, 5 \%, 10 \%, 15 \%, 20 \%$ dan $25 \%$. Hasil penelitian menunjukkan bahwa perlakuan pemberian garam dapur dan $\mathrm{CuSO}_{4}$ dengan konsentrasi yang berbeda berpengaruh terhadap pertumbuhan alga Cyanophyta. Hal tersebut dibuktikan dengan adanya hambatan pertumbuhan alga pada $\mathrm{NaCl}$ lebih baik dibandingkan dengan $\mathrm{CuSO}_{4}$ kecuali pada konsentrasi $10 \%$. Alga Cyanophyta yang diisolasi dari batu bata bahan bangunan pura di desa Tejakula Buleleng juga tumbuh dengan baik pada media aquadest
\end{abstract}

Kata kunci : Alga Cyanophyta, diisolasi, garam dapur, cupri sulphat

\begin{abstract}
The research was about the effect of salt $(\mathrm{NaCl})$ and cupri sulphate $\left(\mathrm{CuSO}_{4}\right\}$ against the growth of algae Cyanophyta aims to compare the administration of various concentrations of $\mathrm{NaCl}$ with $\mathrm{CuSO}_{4}$ in inhibiting the growth of algae Cyanophyta isolated from brick temple building in the village of Tejakula Buleleng. This study used the randomized pre-posttest control group design. The procedure was started with data collection, observation of objects by counting the number of algae growth in medium which given salt concentration and cupri sulphate with concentrations of $0 \%, 5 \%, 10 \%, 15 \%, 20 \%$ and $25 \%$. The results showed that treatment with salt and $\mathrm{CuSO}_{4}$ in different concentrations affected the Cyanophyta algae growth. The evidence was the existence of barrier to the growth of algae better than $\mathrm{CuSO}_{4}$
\end{abstract}


except in concentration $10 \%$. Algae Cyanophyta isolated from brick temple building materials in Tejakula Village Buleleng grew well on aquadest medium.

Keywords : Cyanophyta algae, isolated, salt, cupri sulphat

\section{PENDAHULUAN}

Bali dikenal sebagai pulau seribu pura karena dominan masyarakatnya beragama Hindu. Pura merupakan tempat ibadah dimana umat hindu melakukan upacara keagamaan. Konstruksi pura di Bali lebih banyak dibangun dengan bahan dasar bebatuan seperti batu bata, batu paras dan batu merah. Tujuan penggunaan bebatuan dalam konstruksi pura adalah untuk memperkokoh bangunan pura tersebut seperti halnya penggunaan batu bata.

Batu bata merupakan salah satu bahan bangunan penting berbahan tanah liat (lempung) dengan atau tambahan bahan lain. Batu bata yang baik sebagian besar terdiri atas pasir (silika) dan tanah liat (alumina), yang dicampur dengan perbandingan tertentu, sehingga bila ditambahkan sedikit air bersifat plastis. Kapur yang ditambahkan dalam pembuatan batu bata berguna untuk membantu proses pelelehan pasir saat pembakaran, dan mengikat butir-butir tanah. Kapur ini akan bereaksi dan mengembang bila terkena kandungan air sehingga dapat merekatkan batu bata. Akan tetapi bila terlalu banyak kapur, batu bata akan retak. Selain kapur, batu bata yang baik harus mengandung sedikit oksida besi karena bentuk batu bata yang empat persegi panjang, bersudut sikusiku tajam dan permukaannya rata (Swastikawati, 2012).

Iklim tropis di Indonesia yang memiliki dua musim yaitu hujan dan kemarau menyebabkan bebatuan yang menjadi bahan bangunan pura ditumbuhi oleh mikroorganisme.

Pertumbuhan mikroorganisme di bebatuan berpengaruh negatif terhadap kokohnya bangunan pura. Beberapa mikroorganisme tersebut menyebabkan batu menjadi rapuh dan melapuk. Pelapukan yang terjadi berdampak negatif terhadap konstruksi bangunan yang melemah, nilai kesucian dan keindahan pura menurun serta aktivitas beribadah masyarakat menjadi terganggu. Dampak negatif tersebut menyebabkan masyarakat mencari solusi untuk menanggulangi pelapukan oleh mikroorganisme dengan menggunakan bahan yang mudah ditemukan di kehidupan masyarakat sehingga masa kokoh dari bangunan menjadi lebih lama dan kuat.

Penanggulangan pelapukan bahan bangunan dapat dilakukan dengan cara fisika maupun kimia. Metode ElektroOsmosis dengan menggunakan sinyal DC dan sinyal EOP (Electro-Osmosis Pulse) $30 \mathrm{~V}$ dapat mengendalikan air dalam batu bata (Wicaksono, 2012) dimana diketahui, makhluk hidup tidak kecuali mikroorganisme antara lain alga sangat membutuhkan air dalam pertumbuhannya. Bahan kimia yang dapat digunakan untuk mengisi "nat" diantara batu candi antara lain epoksi resin (resin sintetis) untuk konservasi candi borobudur (Gunawan, dkk., 2011). Selain itu ada zat kimia sebagai desinfektan yaitu Klorin, lodin, Alkohol, Amonium Kuartener, formaldehida, Kalium permanganat dan fenol. Jenis-jenis disinfektan selain digunakan untuk menghambat pertumbuhan mikroorganisme 
juga memiliki dampak negatif bagi kesehatan. Dampak negatifnya seperti resiko keracunan, polusi terhadap lingkungan, resiko terhadap kesehatan serta efek karsinogen. Untuk meminimalisir dampak negatif dari zat disinfektan maka perlu ditemukan bahan pengawet yang ramah lingkungan.

Garam dapur $(\mathrm{NaCl})$ merupakan salah satu bahan makanan yang sudah memasyarakat. Selama ini pemanfaatan garam dapur di masyarakat sebagai bahan penyedap dan pengawet makanan. Kemampuan garam dapur untuk mengawetkan makanan pada dasarnya adalah kemampuan garam dalam menghambat

pertumbuhan mikroorganisme. Kemampuan menghambat bakteri tersebut disebabkan oleh kandungan ion khlor yang beracun terhadap mikroorganisme serta dapat mengganggu kerja enzim proteolitik karena dapat mengakibatkan terjadinya denaturasi protein. Kemampuan ini dapat menjadi salah satu solusi untuk menghambat pertumbuhan mikroorganisme yang tumbuh di batuan bahan dasar bangunan pura di desa Tejakula Buleleng khususnya dan di Bali umumnya sehingga pelapukan yang menjadi permasalahan masyarakat dapat ditanggulangi.

Berdasarkan paparan tersebut, maka penelitian ini dipandang perlu dilakukan untuk membuktikan kebenaran kemampuan garam dapur sebagai penghambatan pertumbuhan mikroorganisme yang terdapat di batu bata bahan bangunan pura di desa Tejakula Buleleng.

\section{METODE}

Penelitian ini adalah penelitian dengan jenis eksperimental sungguhan. Penelitian ini adalah membandingkan pengaruh konsentrasi garam dapur dan konsentrasi cupri sulphat dengan konsentrasi $0 \%, 5 \%, 10 \%, 15 \%, 20 \%$, dan $25 \%$ dalam menghambat pertumbuhan alga Cyanophyta yang diisolasi dari batu bata bangunan pura di desa Tejakula Buleleng.

Berdasarkan jenis penelitian yang akan dilaksanakan, maka didapatkan suatu rancangan penelitian dengan menggunakan the randomized pre- post-test control group design. Rancangan penelitian yang digunakan dalam penelitian ini adalah Rancangan Acak Lengkap (RAL). Pada setiap kelompok perlakuan terdiri atas 5 replikasi. Jumlah pengulangan ini diperoleh dengan rumus yaitu: $t(r-1) \geq 20$ dengan $t=$ jumlah perlakuan, $r=$ jumlah pengulangan (Gazpersz, 1991).

Populasi penelitian ini adalah seluruh alga yang tumbuh pada batu bata bahan dasar bangunan pura yang telah lapuk di desa Tejakula Buleleng. Sampel dalam penelitian ini adalah biakan murni alga Cyanophyta yang diisolasi dari batu bata bahan dasar pembuatan bangunan pura di desa Tejakula Buleleng. Pengambilan sampel ditetapkan dengan teknik acak sederhana (simple random sampling) dengan menggunakan undian.

Variabel bebas dari penelitian ini adalah konsentrasi garam dapur dan cupri sulphat yang variasi konsentrasinya adalah $0 \%, 5 \%, 10 \%, 15 \%, 20 \%$, dan $25 \%$.

Dalam penelitian ini yang menjadi variabel terikatnya adalah jumlah alga cyanophyta yang diisolasi dari batu bata bangunan pura yang telah lapuk di desa Tejakula Buleleng karena perlakuan garam dapur dan cupri sulfat dengan konsentrasi $0 \%, 5 \%, 10 \%, 15 \%, 20 \%$, dan $25 \%$.

Variabel kontrol dalam penelitian ini adalah media pertumbuhan alga Cyanophyta pada media Blue Green Media- 
11 (BGM-11 : Sigma), lingkungan isolasi, lingkungan inkubasi dan instrumen penelitian.

Dalam penelitian ini hanya digunakan instrumen diantaranya, stapler, karet gelang, tabung reaksi, pengaduk, gelas ukur, pipet tetes, beker glass volume 1 liter, neraca analitis, Paper disc, catton swab, jarum ose, Tabung Erlenmeyer, sendok, lampu bunsen, hot plate, autoclave.

Dalam pengumpulan data, obyek diamati dengan menghitung jumlah alga cyanophyta pada media pertumbuhan yang diberikan konsentrasi garam dapur dan cupri sulphat dengan konsentrasi $0 \%, 5 \%$, $10 \%, 15 \%, 20 \%$ dan $25 \%$.
Data dianalisis dengan UNIVARIAT. Jika terdapat perbedaan yang bermakna pada masing-masing perlakuan, dilakukan uji Beda Nyata Terkecil (BNT) pada taraf $5 \%$. Analisis jumlah alga sebelum dan sesudah perlakuan dianalisis dengan Gain score

$=$ Jumlah alga max (sebelum) - Jumlah alga min (setelah)

\section{HASIL DAN PEMBAHASAN}

Keadaan lingkungan yang diukur pada penelitian ini seperti tercantum pada tabel 1 dan tabel 2 di bawah ini.

Tabel 1. Data Keadaan Lingkungan Pertumbuhan Alga pada Media BG-11 dan Media Perlakuan (10 hari setelah inkubasi)

\begin{tabular}{|c|c|c|c|c|}
\hline Lingkungan Fisik & $\begin{array}{l}\text { Suhu } \\
\left({ }^{\circ} \mathrm{C}\right)\end{array}$ & Kelembaban & $\begin{array}{l}\text { Kadar Air } \\
(\%)\end{array}$ & $\begin{array}{l}\text { Besaran } \\
\text { cahaya (pada } \\
20000 \\
\text { Luxmeter) } \\
\end{array}$ \\
\hline $\begin{array}{l}\text { 1. Tempat Tumbuh Alga di Desa } \\
\text { Tejakula (pukul 09.00-09.30) } \\
\text { WITA }\end{array}$ & 28 & 20 & 58 & 001 \\
\hline 2. Pagi hari (pukul 09.00-9.30) WITA & 28 & 20 & $58-60$ & 001-052 \\
\hline $\begin{array}{l}\text { 3. Siang hari (pukul 13.00-14.00) } \\
\text { WITA }\end{array}$ & $28-30$ & $20-25$ & $60-64$ & $700-744$ \\
\hline $\begin{array}{l}\text { 4. Sore hari (pukul 18.00-18.15) } \\
\text { WITA }\end{array}$ & 30 & 5 & 40 & 000-001 \\
\hline
\end{tabular}

Tabel 2. Data $\mathrm{pH}$ medium perlakuan dan medium kontrol

\begin{tabular}{lcc}
\hline Jenis Media & $\begin{array}{c}\text { pH sebelum alga } \\
\text { ditumbuhkan }\end{array}$ & $\begin{array}{c}\text { pH medium setelah } \\
\text { alga ditumbuhkan }\end{array}$ \\
\hline Media kontrol CuSO4 & 4 & 5 \\
Media kontrol NaCl & 7 & 7 \\
Media kontrol aquadest & 7 & 7 \\
Media CuSO4 15\% & 4 & 3 \\
Media CuSO4 25\% & 4 & 2 \\
\hline
\end{tabular}

Interaksi konsentrasi dan perlakuan pada penelitian ini dapat dilihat pada gambar 1. Pada gambar 1 menunjukkan ada interaksi antara konsentrasi dan perlakuan dalam menghambat 
pertumbuhan alga yang ditandai adanya perpotongan garis grafik dari perlakuan.

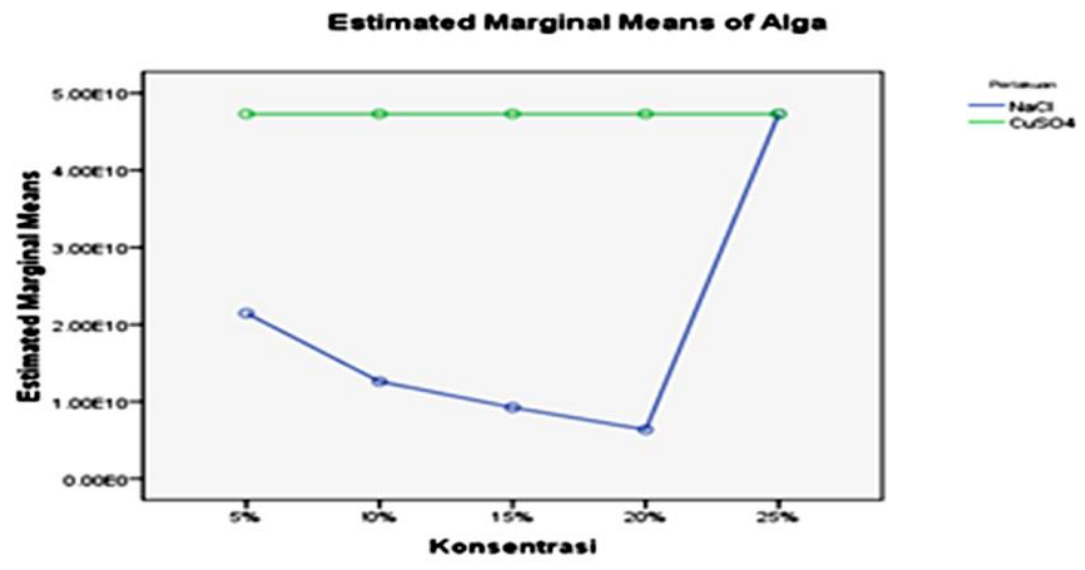

Gambar 1. Grafik yang menunjukkan Interaksi konsentrasi dan perlakuan dalam menghambat pertumbuhan alga.

Tabel 3. Jumlah alga setelah perlakuan $\mathrm{NaCl}$ dan $\mathrm{CuSO}_{4}$

\begin{tabular}{|c|c|c|c|c|c|c|c|}
\hline $\begin{array}{c}\text { Konsentrasi } \\
\text { Replikasi }\end{array}$ & $10^{-1}$ & $10^{-2}$ & $10^{-3}$ & $10^{-4}$ & $10^{-5}$ & Rata-rata & CCRC \\
\hline$\underset{1}{\mathrm{NaCl} 5 \%}$ & 2010 & 37300 & 255000 & 980000 & $\begin{array}{c}97000 \\
00\end{array}$ & 2194862 & $\begin{array}{c}219486 \\
20000\end{array}$ \\
\hline 2 & 2110 & 26500 & 259000 & 1140000 & $\begin{array}{c}86000 \\
00\end{array}$ & 2005522 & $\begin{array}{c}200552 \\
20000\end{array}$ \\
\hline 3 & 3290 & 21000 & 234000 & 1020000 & $\begin{array}{c}99000 \\
00\end{array}$ & 2235658 & $\begin{array}{c}223565 \\
80000\end{array}$ \\
\hline $\begin{array}{c}\text { CuSO4 5\% } \\
1\end{array}$ & 3980 & 38200 & 378000 & 3110000 & $\begin{array}{c}32000 \\
000\end{array}$ & 7106036 & $\begin{array}{c}710603 \\
60000\end{array}$ \\
\hline 2 & 3420 & 29900 & 300000 & 3410000 & $\begin{array}{c}30000 \\
000\end{array}$ & 6748664 & $\begin{array}{c}674866 \\
40000\end{array}$ \\
\hline 3 & 3610 & 23100 & 223000 & 3190000 & $\begin{array}{c}10100 \\
000\end{array}$ & 2707942 & $\begin{array}{c}270794 \\
20000\end{array}$ \\
\hline$\underset{1}{\mathrm{NaCl} 10 \%}$ & 2520 & 22200 & 156000 & 1410000 & $\begin{array}{c}39000 \\
00\end{array}$ & 1098144 & $\begin{array}{c}109814 \\
40000\end{array}$ \\
\hline 2 & 2210 & 20100 & 168000 & 1630000 & $\begin{array}{c}63000 \\
00\end{array}$ & 1624062 & $\begin{array}{c}162406 \\
20000\end{array}$ \\
\hline 3 & 1590 & 18900 & 143000 & 1120000 & $\begin{array}{c}40000 \\
00\end{array}$ & 1056698 & $\begin{array}{c}105669 \\
80000\end{array}$ \\
\hline $\begin{array}{c}\text { CuSO } 410 \% \\
1\end{array}$ & 4010 & 38300 & 400000 & 3000000 & $\begin{array}{c}18500 \\
000\end{array}$ & 4388462 & $\begin{array}{c}438846 \\
20000\end{array}$ \\
\hline
\end{tabular}




\begin{tabular}{|c|c|c|c|c|c|c|c|}
\hline $\begin{array}{c}\text { Konsentrasi } \\
\text { Replikasi }\end{array}$ & $10^{-1}$ & $10^{-2}$ & $10^{-3}$ & $10^{-4}$ & $10^{-5}$ & Rata-rata & CCRC \\
\hline 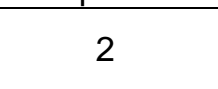 & 2680 & 33300 & 377000 & 3020000 & $\begin{array}{c}12300 \\
000\end{array}$ & 3146596 & $\begin{array}{c}314659 \\
60000\end{array}$ \\
\hline 3 & 2790 & 32100 & 370000 & 2670000 & $\begin{array}{c}17200 \\
000\end{array}$ & 4054978 & $\begin{array}{c}405497 \\
80000\end{array}$ \\
\hline$\underset{1}{\mathrm{NaCl} 15 \%}$ & 1440 & 13600 & 90000 & 710000 & $\begin{array}{c}29000 \\
00\end{array}$ & 743008 & $\begin{array}{c}743008 \\
0000\end{array}$ \\
\hline 2 & 930 & 9700 & 29000 & 450000 & $\begin{array}{c}33000 \\
00\end{array}$ & 757926 & $\begin{array}{c}757926 \\
0000\end{array}$ \\
\hline 3 & 690 & 9900 & 66000 & 270000 & $\begin{array}{c}60000 \\
00\end{array}$ & 1269318 & $\begin{array}{c}126931 \\
80000\end{array}$ \\
\hline $\begin{array}{c}\text { CuSO4 } 15 \% \\
1\end{array}$ & 1510 & 21500 & 198000 & 1690000 & $\begin{array}{c}10800 \\
000\end{array}$ & 2542202 & $\begin{array}{l}254220 \\
20000\end{array}$ \\
\hline 2 & 1210 & 13500 & 210000 & 1290000 & $\begin{array}{c}13000 \\
000\end{array}$ & 2902942 & $\begin{array}{c}290294 \\
20000\end{array}$ \\
\hline 3 & 1130 & 10200 & 189000 & 1010000 & $\begin{array}{c}16500 \\
000\end{array}$ & 3542066 & $\begin{array}{c}354206 \\
60000\end{array}$ \\
\hline $\begin{array}{c}\mathrm{NaCl} 20 \% \\
1\end{array}$ & 1100 & 9900 & 29000 & 290000 & $\begin{array}{c}27000 \\
00\end{array}$ & 606000 & $\begin{array}{c}606000 \\
0000\end{array}$ \\
\hline 2 & 720 & 8700 & 24000 & 280000 & $\begin{array}{c}30000 \\
00\end{array}$ & 662684 & $\begin{array}{c}662684 \\
0000\end{array}$ \\
\hline 3 & 320 & 4500 & 35000 & 250000 & $\begin{array}{c}29000 \\
00\end{array}$ & 637964 & $\begin{array}{c}637964 \\
0000\end{array}$ \\
\hline $\begin{array}{c}\text { CuSO4 } 20 \% \\
1\end{array}$ & 1030 & 19800 & 171000 & 930000 & $\begin{array}{c}72000 \\
00\end{array}$ & 1664366 & $\begin{array}{l}166436 \\
60000\end{array}$ \\
\hline 2 & 1980 & 13000 & 123000 & 1000000 & $\begin{array}{c}88000 \\
00\end{array}$ & 1987596 & $\begin{array}{c}198759 \\
60000\end{array}$ \\
\hline 3 & 950 & 15400 & 93000 & 950000 & $\begin{array}{c}11100 \\
000\end{array}$ & 2431870 & $\begin{array}{c}243187 \\
00000\end{array}$ \\
\hline $\begin{array}{c}\mathrm{NaCl} 25 \% \\
1\end{array}$ & 1200 & 3300 & 45000 & 300000 & $\begin{array}{c}29000 \\
00\end{array}$ & 649900 & $\begin{array}{c}649900 \\
0000\end{array}$ \\
\hline 2 & 1010 & 3700 & 60000 & 590000 & $\begin{array}{c}27000 \\
00\end{array}$ & 670942 & $\begin{array}{c}670942 \\
0000\end{array}$ \\
\hline 3 & 840 & 6500 & 70000 & 310000 & $\begin{array}{c}24000 \\
00\end{array}$ & 557468 & $\begin{array}{c}557468 \\
0000\end{array}$ \\
\hline $\begin{array}{c}\text { CuSO } 4 \text { 25\% } \\
1\end{array}$ & 1220 & 12900 & 210000 & 1290000 & $\begin{array}{c}93000 \\
00\end{array}$ & 2162824 & $\begin{array}{l}216284 \\
20000\end{array}$ \\
\hline 2 & 1240 & 10200 & 101000 & 1170000 & $\begin{array}{c}76000 \\
00\end{array}$ & 1776488 & $\begin{array}{c}177648 \\
80000\end{array}$ \\
\hline 3 & 1200 & 16800 & 191000 & 290000 & $\begin{array}{c}10300 \\
000\end{array}$ & 2159800 & $\begin{array}{c}215980 \\
00000\end{array}$ \\
\hline
\end{tabular}

Tabel 4. Jumlah alga biakan murni yang diisolasi dari batu bata bahan bangunan pura di desa Tejakula Buleleng dalam aquadest.

\begin{tabular}{lllllllll}
\hline Aquade & $10-1$ & $10-2$ & $10-3$ & $10-4$ & $10-5$ & Rata- & CCRC & Pertumbuh \\
\hline
\end{tabular}




\begin{tabular}{|c|c|c|c|c|c|c|c|c|}
\hline \multirow[t]{3}{*}{$\begin{array}{c}\text { st } \\
\text { (treatme } \\
n t)\end{array}$} & & & & & & $\begin{array}{c}\text { rata } \\
\text { pertumb } \\
\text { uhan } \\
\text { alga }\end{array}$ & $\begin{array}{l}\text { pertumbu } \\
\text { han alga } \\
\text { dalam } \\
\text { aquadest }\end{array}$ & $\begin{array}{c}\text { an alga } \\
\text { sebelum } \\
\text { perlakuan } \\
\text { dalam BG- } \\
11 \text { (CCRC) }\end{array}$ \\
\hline & 6930 & 57900 & 529000 & $\begin{array}{c}55500 \\
00\end{array}$ & $\begin{array}{c}48900 \\
000\end{array}$ & $\begin{array}{c}110087 \\
66\end{array}$ & $\begin{array}{c}1,10088 \mathrm{E} \\
+11\end{array}$ & $\begin{array}{c}473027800 \\
00\end{array}$ \\
\hline & \multicolumn{7}{|c|}{ Gain pertumbuhan alga dalam media aquadest - BG-11 } & $6,28 \mathrm{E}+10$ \\
\hline
\end{tabular}

Rata-rata gain score jumlah pertumbuhan sel alga dalam setiap mililiter sebelum dan sesudah perlakuan setiap konsentrasi dan dibandingkan dengan biakan murni yang ditumbuhkan dalam aquadest dirangkum dalam tabel 5 di bawah ini.

Tabel 5. Gain score jumlah sel alga/ml sebelum dan sesudah perlakuan dan gain biakan murni dalam aquadest

\begin{tabular}{lccc}
\hline Perlakuan & $\begin{array}{c}\text { Rata-rata } \\
\text { pertumbuhan alga } \\
(\mathrm{CCRC})\end{array}$ & $\begin{array}{c}\text { Gain jumlah sel alga } \\
\text { sebelum dan sesudah } \\
\text { perlakuan pada media } \\
\text { BG-11 }\end{array}$ & $\begin{array}{c}\text { CCRC Aquadest- } \\
\text { CCRC perlakuan }\end{array}$ \\
\hline $\mathrm{NaCl}$ 5\% & 21453473333 & 25849326667 & $8,86 \mathrm{E}+10$ \\
$\mathrm{CuSO} 45 \%$ & 55208806667 & -7906006667 & $5,49 \mathrm{E}+10$ \\
$\mathrm{NaCl} \mathrm{10 \%}$ & 12596346667 & 34706453333 & $9,75 \mathrm{E}+10$ \\
$\mathrm{CuSO} 410 \%$ & 38633453333 & 8669346667 & $7,15 \mathrm{E}+10$ \\
$\mathrm{NaCl} \mathrm{15 \%}$ & 9234173333 & 38068626667 & $1,01 \mathrm{E}+11$ \\
$\mathrm{CuSO} 415 \%$ & 29957366667 & 17345433333 & $8,01 \mathrm{E}+10$ \\
$\mathrm{NaCl} 20 \%$ & 6355493333 & 40947306667 & $1,04 \mathrm{E}+11$ \\
$\mathrm{CuSO} 420 \%$ & 20279440000 & 27023360000 & $8,98 \mathrm{E}+10$ \\
$\mathrm{NaCl} \mathrm{25 \%}$ & 6261033333 & 41041766667 & $1,04 \mathrm{E}+11$ \\
$\mathrm{CuSO} 425 \%$ & 20330433333 & 26972366667 & $8,98 \mathrm{E}+10$ \\
\hline
\end{tabular}

Tabel 6. Jumlah alga yang diisolasi dari batu bata bahan bangunan pura desa Tejakula Buleleng dalam media kontrol

\begin{tabular}{lcc}
\hline & Kontrol & CCRC \\
\hline $\mathrm{NaCl}$ & 0 & 0 \\
$\mathrm{CuSO}_{4}$ & 0 & 0 \\
Aquadest & 0 & 0 \\
\hline
\end{tabular}


Tabel 7. Rata-rata jumlah alga yang tumbuh pada setiap konsentrasi dan Gain score setiap konsentrasi

\begin{tabular}{|c|c|c|}
\hline $\begin{array}{l}\text { Rata-rata jumlah sel } \\
\text { alga/ml }\end{array}$ & Rata-rata Pertumbuhan (CCRC) & $\begin{array}{c}\text { Gain pertumbuhan setiap } \\
\text { konsentrasi perlakuan antara } \\
\text { CuSO4 dengan } \mathrm{NaCl}\end{array}$ \\
\hline $\mathrm{NaCl} 5 \%$ & 21453473333 & \multirow{2}{*}{$3,38 \mathrm{E}+10$} \\
\hline CuSO4 5\% & 55208806667 & \\
\hline $\mathrm{NaCl} 10 \%$ & 12596346667 & \multirow{2}{*}{$2,60 E+10$} \\
\hline CuSO4 10\% & 38633453333 & \\
\hline $\mathrm{NaCl} 15 \%$ & 9234173333 & \multirow{2}{*}{$2,07 \mathrm{E}+10$} \\
\hline CuSO4 15\% & 29957366667 & \\
\hline $\mathrm{NaCl} 20 \%$ & 6355493333 & \multirow[t]{2}{*}{$1,39 \mathrm{E}+10$} \\
\hline CuSO4 20\% & 20279440000 & \\
\hline $\mathrm{NaCl} 25 \%$ & 6261033333 & \multirow[t]{2}{*}{$1,41 \mathrm{E}+10$} \\
\hline CuSO4 25\% & 20330433333 & \\
\hline \multicolumn{2}{|c|}{ Gain CuSO4 25\%-CuSO4 20\% } & $5,10 \mathrm{E}+07$ \\
\hline
\end{tabular}

Alga Cyanophyta, alga hijau-biru berbeda dengan alga yang lainnya. Alga ini memiliki pigmen yang terlokalisasi di kromatophora tertentu yaitu bagian peripheral protoplast dan termasuk ke dalam klorophil $\alpha$, karotin dan xantophylls. Alga ini juga mempunyai pigmen biru yaitu c-phycocyanin dan pigmen merah yaitu cphycoerythrin. Keunikan lain dari cyanophyta adalah nukleus yang primitif, badan pusat dan tidak ada membran nukleolus dan nukleolus. Habitatnya biasanya di air tawar, bebatuan yang basah atau tanah basah. Ada juga tumbuh di air panas dengan suhu $85^{\circ} \mathrm{C}$. Pada air panas dengan karakteristik air dengan kalsium dan komponen senyawa magnesium, khususnya bikarbonat terlarut, alga hijau biru menyebabkan presipitasi (endapan) garam kalsium dan magnesium dalam membentuk karbonat yang tidak larut. Jumlah karbonat yang terendepkan itu juga memungkinkan material tersimpan dengan ketebalan 2-4 $\mathrm{mm}$ selama seminggu berjalan. Pada teras dasar air itu membentuk warna yang cemerlang oleh lapisan alga (Smith, 1955)
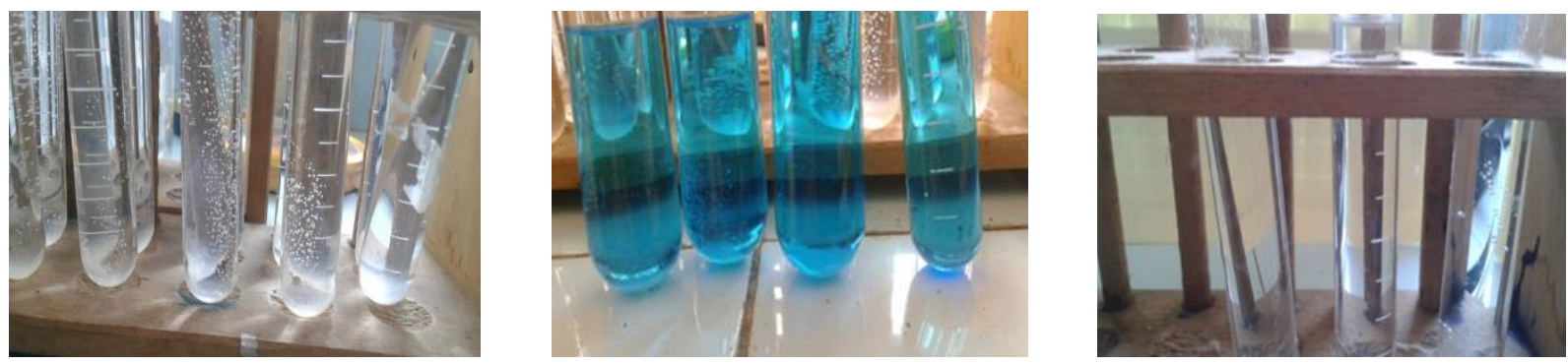

Gambar 1. Bubble pada perlakuan (dokumentasi peneliti) 
Hasil penelitian didapatkan bahwa jumlah alga yang diisolasi dari bahan bangunan pura di desa Tejakula Buleleng dan ditumbuhkan pada media BG-11 adalah $4,7302780.10^{10} \mathrm{sel} / \mathrm{ml}$. Alga yang terisolasi, dipengaruhi oleh kondisi lingkungan antara lain: suhu udara, $\mathrm{pH}$, kadar air, kelembaban, jumlah cahaya. Suhu udara di desa Tejakula pada bulan Oktober 2014 adalah $28-30^{\circ} \mathrm{C}$. Sampel yang diambil di batuan batu bata bahan bangunan pura dengan 2 daerah transek yang berukuran $1 \mathrm{~cm} \times 1 \mathrm{~cm}$. Pertumbuhan alga dan perlakuan untuk mengetahui daya hambat dilakukan pada bulan OktoberNopember 2014 di laboratorium mikrobiologi pada media BG-11. Suhu udara ruangan di laboratorium berkisar 28$30^{\circ} \mathrm{C}$ dan jumlah cahaya tertinggi pada siang hari yaitu 700-744 luxmeter (tabel 1). Kondisi ini memungkinkan tumbuhnya alga cyanophyta karena mempunyai pigmen klorofil yang terdapat pada protoplas untuk forosintesis. Kadar air dan kelembaban yang tinggi baik di daerah tempat mengisolasi alga dan kondisi di laboratorium masing-masing berkisar 5864\% dan 20-25 memungkinkan alga untuk tumbuh, karena umumnya hidup di lingkungan perairan, daerah musim hujan dan daratan.

Perpaduan suhu tropik, kadar air dan kelembaban memberikan tumbuh suburnya alga pada medium BG-11 dan juga dalam media aquadest. Alga cyanophyta juga tumbuh pada air panas dengan suhu optimal $85^{\circ} \mathrm{C}$. Pertumbuhan alga di dalam aquadest menunjukkan lebih tinggi dibandingkan di medium BG-11 (tabel 4), dengan gain score: $6,28 \mathrm{E}+10 \mathrm{sel} / \mathrm{ml}$. Perlakuan kultur murni mikroalga cyanophyta yang ditumbuhkan dalam aquadest menunjukkan pertumbuhan yang tinggi (tabel 4), dengan jumlah sel alga/ml adalah $1,10088 \mathrm{E}+11$. Hal ini sesuai dengan pernyataan Smith (1955) bahwa habitat alga cyanophyta biasanya di air tawar, bebatuan yang basah atau tanah basah.

Aquadest merupakan media yang baik untuk pertumbuhan alga (tabel 4). Tabel 6 menunjukkan bahwa media kontrol yaitu $\mathrm{NaCl}$, CuSO4 dan aquadest tidak terkontaminasi oleh alga. Hasil penelitian menunjukkan bahwa terjadi hambatan pertumbuhan alga karena perlakuan dengan mencari gain sebelum dan sesudah perlakuan (tabel 5) untuk setiap konsentrasi $\mathrm{NaCl}$ dan $\mathrm{CuSO} 4$, kecuali pada perlakuan CuSO4 10\%, dimana pertumbuhan alga pada konsentrasi ini lebih tinggi dibandingkan sebelum perlakuan. Ini dimungkinkan karena Cu merupakan unsur mikro yang diperlukan dalam pertumbuhan tanaman dan sebagai induser tumbuhan tertentu (Arifin, 2007) dan Sartini, dkk. (2010). CuSO4 merupakan elemen mikro yang dibutuhkan untuk pertumbuhan blue green algae (James, 1978).

Perlakuan $\mathrm{pH}$ medium mempengaruhi tumbuhnya alga. Aquadest dan $\mathrm{NaCl}$ mempunyai $\mathrm{pH}$ yang netral, sedangkan CuSO4 mempunyai $\mathrm{pH}$ yang asam (tabel 2). Menurut Kaseno (BPPT, 2002), karakteristik media dengan $\mathrm{pH}$ asam yaitu mengendapkan ion-ion anorganik seperti kalsium, magnesium, natrium. Ini memungkinkan alga cyanophyta tumbuh dengan baik di batu bahan bangunan pura dimana bahan dasar batuan ini adalah tanah liat yang mengandung antara lain $\mathrm{Na}$ dan $\mathrm{Mg}, \mathrm{Ca}$, Si (Sitohang dan Hazairin, 2002). Dilihat dari komposisi dari media BG-11 yang merupakan media pertumbuhan cyanophyta dimana mineral tersebut merupakan komposisi penyusun media pertumbuhan cyanophyta. Secara 
lengkap media pertumbuhan cyanophyta adalah $\mathrm{NaNO} 3: 1,59 \mathrm{~g} ; \mathrm{K}_{2} \mathrm{HPO}_{4}: 0,039 \mathrm{~g}$; $\mathrm{MgSO}_{4} .7 \mathrm{H}_{2} \mathrm{O}: 0,075 \mathrm{~g} ; \mathrm{Na}_{2} \mathrm{CO}_{3}: 0,02 \mathrm{~g}$; $\mathrm{Ca}\left(\mathrm{NO}_{3}\right)_{2} \cdot 4 \mathrm{H}_{2} \mathrm{O}$ : $0,02 \mathrm{~g} ; \mathrm{Na}_{2} \mathrm{SiO}_{3} \cdot 9 \mathrm{H}_{2} \mathrm{O}$ : 0,058 g; EDTA : 0,001 g; Citric acid : 0,006 $\mathrm{g} ; \mathrm{FeCl}_{3}: 0,002 \mathrm{~g}$; Microelement $1 \mathrm{ml}$ yang terdiri dari : $\mathrm{H}_{2} \mathrm{BO}_{4}: 2,86 \mathrm{~g} ; \mathrm{MnCl}_{2} .4 \mathrm{H}_{2} \mathrm{O}$ $: 1,81 \quad$ g; $\quad \mathrm{ZnSO} 4.7 \mathrm{H} 2 \mathrm{O} \quad: \quad 0,222$ g; $\mathrm{NaMoO}_{4} \cdot 2 \mathrm{H}_{2} \mathrm{O}: 0,391 \mathrm{~g} ; \mathrm{CuSO}_{4} \cdot 5 \mathrm{H}_{2} \mathrm{O}$ : 0,079g; $\mathrm{Co}\left(\mathrm{NO}_{3}\right)_{2} \cdot 0,0494 \mathrm{~g}$ (James, 1978). Terendapkannya ion-ion anorganik itu menyebabkan bikarbonat menjadi tidak larut karena pertumbuhan alga. Kapur (karbonat) atau $\mathrm{CO}_{3}$ yang ditambahkan ke dalam tanah liat dalam pembuatan batu bata, berguna untuk membantu proses pelelehan pasir saat pembakaran batu bata, dan mengikat butir-butir tanah. Kapur ini akan akan bereaksi dan mengembang bila terkena kandungan air sehingga dapat merekatkan batu bata (Swastikawati, 2012).

Hasil penelitian menunjukkan bahwa perlakuan $\mathrm{NaCl}$ dan $\mathrm{CuSO}_{4}$ terhadap pertumbuhan alga, $\mathrm{NaCl}$ menghambat pertumbuhan alga lebih baik dibandingkan dengan dengan CuSO4 (tabel 3, 4 dan 5.). Setelah diberikan perlakuan garam $\mathrm{NaCl}$ dan $\mathrm{CuSO}_{4}$ dengan konsentrasi $5 \%, 10 \%$, $15 \%$, 20\% dan 25\% didapatkan hasil seperti tabel 3. Garam dapur $(\mathrm{NaCl})$ berfungsi sebagai penghambat pertumbuhan mikroorgnisme pembusuk dan patogen karena mempunyai sifat-sifat anti mikroorganisme yaitu akan meningkatkan tekanan osmotik substrat, menyebabkan terjadinya penarikan air dari dalam sel mikroorganisme sehingga sel akan kehilangan air dan mengalami pengerutan, ionisasi garam akan menghasilkan ion khlor yang beracun terhadap mikroorganisme, serta dapat mengganggu kerja enzim proteolitik karena dapat mengakibatkan terjadinya denaturasi protein (Winiati, 1992). Hal ini pula diungkapkan oleh Estiasih (2009) yang menyatakan bahwa penambahan garam berfungsi mengawetkan karena kadar garam yang tinggi menghasilkan tekanan osmotik yang tinggi dan aktivitas air rendah. Kondisi ekstrim ini menyebabkan kebanyakan mikroorganisme tidak dapat hidup (Estiasih, 2009). Cupri sulphat $\left(\mathrm{CuSO}_{4}\right)$ juga dinyatakan sebagai penghambat mikroorganisme antara lain jamur, alga, dan bakteri (Suheryanto, 2010), anti lumut pada kolam renang (Sukma, 2013), tetapi dari data didapatkan CuSO4 menghambat pertumbuhan alga lebih rendah dibandingkan $\mathrm{NaCl}$.

Tabel (3, 4 dan 5) didapatkan bahwa $\mathrm{NaCl}$ menghambat pertumbuhan alga lebih baik dibandingkan $\mathrm{CuSO}_{4}$ untuk semua konsentrasi yaitu 5\%,10\%,15\%, 20\% dan $25 \%$. Penelitian Sartini dkk (2010), $\mathrm{CuSO}_{4}$ sebagai induser kapang endofit yang diisolasi dari kulit kakao (Theobroma caccao) untuk menghasilkan enzim polifenol oxidase dimana enzim ini berfungsi untuk mencegah infeksi bakteri pada penderita Parkinson's dan sintesis melanin. Disamping itu juga digunakan secara luas dalam pengolahan makanan. Pada kapang Alternaria sp. enzim ini dihasilkan extraselluler. Ini berarti $\mathrm{CuSO}_{4}$ berfungsi sebagai growth factor untuk enzim tertentu pada fungi. Menurut Arifin (2007) tembaga merupakan unsur mineral mikro yang sangat berperan dalam proses metabolisme tubuh.

Ahmadun, dkk. (2009) menyatakan bahwa $\mathrm{SO}_{4}{ }^{2-}$ merupakan salah satu anion dari zat anorganik yang terlarut pada produced water yaitu stream limbah terbesar yang dihasilkan oleh industri minyak bumi dan gas alam. Luptakova (2007) menyatakan bahwa sulfat ini dapat 
direduksi oleh mikroorganisme yaitu Desulfovibrio desulfuricans yang dapat mengurangi sulfat dalam keadaan anaerob dan dapat membentuk logam sulfida bila atom $\mathrm{S}$ berikatan dengan kation dan logam yang bebas air. Ini berarti bakteri memanfaatkan sulfat dalam pertumbuhannya. Bakteri ini dimanfaatkan dalam pengolahan air seperti yang dinyatakan oleh Bedrikovetsky et al (2006) adanya kandungan sulfat dalam pengolahan produces water secara injeksi ke dalam tanah hanya diperbolehkan dengan nilai konsentrasi kurang dari 400 ppm, karena konsentrasi sulfat yang tinggi akan menyebabkan pembentukan kerak berupa garam sulfat pada aliran perpipaan. Penelitian Darmawan dkk (Tekhnik Kimia Fakultas Teknik Industri, ITS) menunjukkan bahwa Desulfovibrio desulfuricans di dalam metabolismenya juga menghasilkan sulfat, sulfit dan sulfida. Hasil penelitiannya mendapatkan bahwa, pada hari ke-9 mengalami gradien terbesar penggunaan karbon yang ditandai dengan jumlah maksimum bakteri. Sumber karbon etanol yang ditambahkan pada produced water sintetis dinyatakan berpengaruh paling tinggi terhadap penurunan sisa kandungan sulphat. Hal ini pula yang terjadi pada microalgae cyanophyta yang ditumbuhkan dalam media $\mathrm{CuSO}_{4}$. Menurut James (1978) $\mathrm{CuSO}_{4}$ merupakan salah satu elemen mikro yang dibutuhkan dalam pertumbuhan blue green algae. Darmawan (ITS) juga menyatakan bahwa penambahan $\mathrm{Ca}{ }^{2+}$ pada produced water sintetis berpengaruh positif terhadap kerja $D$. desulfuricans dalam mereduksi sulfat dan logam berat. Gas $\mathrm{H}_{2} \mathrm{~S}$ merupakan sisa sulfida hasil metabolisme $D$. desulfiricans yang tidak membentuk logam sulfida. Melihat karakteristik dari sifat kimia $\mathrm{NaCl}$ dan $\mathrm{CuSO}_{4}$ dalam menghambat pertumbuhan alga (jika dibandingkan pertumbuhannya dalam media aquadest), nampak jelas dihambat dilihat dari tabel 5 . Penghambatan yang optimal $\mathrm{CuSO}_{4}$ terhadap pertumbuhan alga dicapai pada konsentrasi $20 \%$.

Konsentrasi $\mathrm{CuSO}_{4} \quad 25 \%$ dalam menghambat pertumbuhan mikroalga cyanophyta lebih sedikit dibandingkan dengan konsentrasi 20\% (tabel 7). Jadi penggunaan optimal untuk menghambat pertumbuhan alga adalah $\mathrm{CuSO}_{4} 20 \%$. Ini sesuai dengan kurva pertumbuhan mikroba yang terdiri dari fase lag, fase logaritmik, fase stasioner dan fase kematian (Cappuccino, 1987). Konsentrasi cuprum yang tinggi menjadi faktor pembatas bagi pertumbuhan mikroalga cyanophyta, seperti yang dikemukakan oleh Tokarnia et al (2000) yang menyatakan bahwa keracunan dari logam $\mathrm{Cu}$ dipengaruhi oleh beberapa faktor antara lain kadar logam yang terkonsumsi, lamanya mengkonsumsi, umur, spesies, jenis kelamin dan kebiasaan makan makanan tertentu. Suheryanto (2010) juga menyatakan bahwa Cupri sulfat $\left(\mathrm{CuSO}_{4}\right)$ juga dinyatakan sebagai penghambat mikroorganisme antara lain jamur, alga, dan bakteri.

\section{PENUTUP}

Berdasarkan hasil analisis dan pembahasan di atas, simpulan dalam penelitian ini antara lain adanya pengaruh konsentrasi garam dapur dan $\mathrm{CuSO}_{4}$ yang berbeda terhadap pertumbuhan alga cyanophyta yang diisolasi dari batu bata bahan bangunan pura di desa Tejakula Buleleng. Terdapat hambatan pertumbuhan alga cyanophyta terhadap perlakuan $\mathrm{NaCl}$ dan $\mathrm{CuSO}_{4}$ kecuali perlakuan $\mathrm{CuSO}_{4}$ 10\% yang ditentukan oleh gain score sebelum 
dan setelah perlakuan. Hambatan pertumbuhan alga cyanophyta menggunakan $\mathrm{NaCl}$ lebih baik dibandingkan dengan $\mathrm{CuSO}_{4} . \quad$ Alga cyanophyta ini juga tumbuh dengan baik pada media aquadest. Saran dari penelitian ini adalah bagi pencetak bahan bangunan seperti batu bata hendaknya formulasi bahan bangunan yang mengandung antimikroba seperti algasida. Bagi masyarakat pengguna bahan bangunan seperti batu bata hendaknya memberikan perlakuan batu bata seperti perendaman dalam $\mathrm{NaCl}$ untuk daya tahan bangunan khususnya dekomposisi dari alga.

\section{DAFTAR PUSTAKA}

Ahmadun, F., Alireza, P., Luqman, C.A., Dayang, R.A. B., Sayed, S.M., Zurina, Z.A. 2009. Review of Technologies for Oil and Gas Produced Water Treatment. J. Of Hazardous Materials. Hazmat $-10003: 1-5$

Arifin, Z. 2007. Pentingnya Mineral Tembaga $(\mathrm{Cu})$ dalam Tubuh Hewan dalam Hubungannya dengan Penyakit. Wartazoa. 17 (2).

Berdrikovetsky., P, G., Eric, J. M., Raphael M.PS., Flavia, M.R.P., Fransiska, F.S. 2009. Produced Water Re-Injection with Seawater Treated by Sulphate Reduction Plant : Injectivity decline, Analitycal Model. J. Of Petroleum Sci and Engineering

Cappuccino, J.G., Sherman, N. 1987. Microbiology: A Laboratory Manual. California, Massachusetts, Ontario, Wokingham, Amsterdam, Sydney, Singapore, Tokyo, Madrid, Bogota, Santiago, San Juan : The Benjamin/Cummings Pub. Company, Inc
Darmawan, R., Hidayat F., Sri, R.J., Farid, E., Dyah, W.R. Laboratorium Pengolahan Limbah Industri. Jurusan Tekhnik Kimia, Fak Teknologi Industri, ITS.

Estiasih, T. 2009. Tekhnologi Pengolahan Pangan. Malang : Bumi Aksara

Gaspersz. V. 1991. Tekhnik Analisa Dalam Penelitian Percobaan. Bandung : Tarsito

Gunawan, A. Cahyandaru, N., Muhamad,

R. 2011. Kajian Pengembangan

Bahan Konservasi. Mortar tradisional

(Hyduaulic Morta) James, D.E. 1978.

Culturing Algae. U.S.A : Carolina

Biological Supply Co.

Kaseno (BPPT. 2002). Pengaruh lon-ion anorganik Terhadap Pengendapan Abu- Molases. Oleh Kaseno. UPTEPG BPP Teknologi Indonesia. Dept of Chemical Engineering, Faculty of Technology. Tokyo University of Agriculture and Technology, Koganei, Tokyo184, Japan.

Luptakova, A. 2007. Importance of Sulphate Reducing Bacteria in Environment. Nova Biotechnologica. 7 (1). Departement of Mineral Biotechnologies, Institute of Geotechnics of Slovak Academy of science, Watsanova, Slovak Republik.

Sartini., Patong, A.R., Halim., Pirman. 2010.

Pengaruh Penambahan Tembaga Sulfat terhadap Produksi Enzim Polifenoloksidase dari Fungi Endofit Kulit Buah Kakao. Fak. Farmasi UNHAS, Jurusan Kimia FMIPA UNHAS dan Poltek Negeri Ujung Pandang Makasar

Sitohang, A dan Hazairin, 2002. Pemanfaatan Kapur dan Pozzolan Sebagai Bahan Baku Utama 
Pembuatan Semen Hidraulis Alternatif. Bandung : ITB

Smith, G.M. 1955. Cryptogamic Botany. Algae and Fungi. Reprinted 1983. New York : McGrow-Hill Book Company, Inc

Swastikawati, A. 2012. Standar Pengujian Kualitas Bata Pengganti. Yogyakarta : Balai Konservasi Peninggalan Burobudur.
Tokarnia, C.H., J. Dobereiner., P.V. Peixoto and S.S. 2000. Outbreak of Copper Poisoning in Cattle Fed Poultry Litter. Vet. Hum. Toxicol. 42(2):92-95

Winiati, P.R. 1992. Penanganan Limbah Industri Pangan. Yogjakarta: Kanisius

Wicaksono, M.A. 2012. Perancangan Sistem Elektro-Osmosis untuk pengendalian air pada batuan candi. Surabaya : ITS 